\title{
PENGEMBANGAN MEDIA PEMBELAJARAN BERBASIS PREZI PADA MATAKULIAH ANALISIS VEKTOR
}

\author{
Dian Fitri Argarini $^{1}$, Yunis Sulistyorini ${ }^{2}$ \\ ${ }^{1}$ IKIP Budi Utomo Malang \\ kejora.subuh14@gmail.com \\ ${ }^{2}$ IKIP Budi Utomo Malang \\ yunis.sulistyorini@gmail.com
}

\begin{abstract}
ABSTRAK
Mahasiswa kesulitan dalam memahami konsep Analisis Vektor yang abstrak dan membutuhkan dukungan visualisasi dalam pembelajaran tersebut. Media pembelajaran Prezi dikembangkan dengan memperhatikan prinsip visual mampu mendukung pembelajaran Analisis Vektor. Penelitian bertujuan untuk mendeskripsikan pengembangan media pembelajaran dan menghasilkan media pembelajaran berbasis Prezi yang layak digunakan dalam pembelajaran. Pengembangan mengacu pada model pengembangan ASSURE (Analyze learners, State objectives, Select methods, media and materials, Utilize media and materials, Require learners ' participation, dan Evaluate and revise). Instrumen penelitian terdiri dari lembar penilaian ahli, soal tes dan angket respon mahasiswa. Media pembelajaran yang dikembangkan layak digunakan dengan memenuhi aspek kevalidan dan keefektifan. Penilaian aspek kevalidan berdasarkan lembar penilaian ahli berada pada kriteria valid. Sedangkan penilaian aspek keefektifan berdasarkan hasil tes mahasiswa berada pada kriteria cukup baik dan angket respon mahasiswa berada pada kriteria sangat baik. Media pembelajaran terdiri dari bagian menu dan bagian isi. Bagian menu terdiri dari gambaran materi yang akan disajikan dalam media. Bagian isi terdiri dari materi yang bisa diperbesar dan diperkecil sesuai kebutuhan dan video pembelajaran untuk memvisualisasikan konsep Analisis Vektor.
\end{abstract}

Kata Kunci: Pengembangan Media, Media Pembelajaran, Prezi, Analisis Vektor

\begin{abstract}
Undergraduate students have difficulties in understanding abstract concept of Vector Analysis and need visualization to support learning. Prezi-based instructional media developed by consider visual principle that support Vector Analysis learning. This study aims to describe Prezi-based instructional media development and produce Prezi-based instructional media that is suitable for learning. Development refers to ASSURE development model (Analyze learners, State objectives, Select methods, media and materials, Utilize media and materials, Require learners' participation, and Evaluate and revise). The research instrument consisted of expert assessment sheets, test questions and student response questionnaires. Instructional media is feasible to be used satisfy aspects of validity and effectiveness. Assessment of the validity aspect based on the experts' judgment that is on a valid criterion. While the assessment of effectiveness aspects based on test results are on quite good criteria and questionnaire responses of undergraduate students are on excellent criteria. Learning media consists of menu sections and content sections. The menu section consists of an overview of the
\end{abstract}


material that will be presented in the media. The content section consists of material that can be zoomed in and zoomed out according to needs and learning videos to visualize the concept of Vector Analysis.

Keywords: Media Development, Instructional Media, Prezi, Vector Analysis

Format Sitasi: Argarini, D. F. \& Sulistyorini, Y. (2018). Pengembangan Media Pembelajaran Berbasis Prezi pada Matakuliah Analisis Vektor. KALAMATIKA Jurnal Pendidikan Matematika, 3(2), 209-222.

Penyerahan Naskah: 1 Januari 2018 || Revisi: 20 September 2018 || Diterima: 25 September 2018

\section{PENDAHULUAN}

Vektor banyak berperan dalam kehidupan nyata. Beberapa penerapan vektor dalam kehidupan nyata misalnya dalam bidang fisika, elektromagnetik, aerodinamika (Spiegel, 1959) dan mekanika (Sari, et. al., 2015). Vektor merupakan salah satu konsep yang wajib dikuasai oleh mahasiswa program studi Pendidikan Matematika yang disajikan dalam matakuliah Analisis Vektor. Matakuliah ini dalam Kurikulum Kerangka Kualifikasi Nasional Indonesia program studi Pendidikan Matematika IKIP Budi Utomo termasuk dalam kelompok matakuliah keilmuan dan keterampilan. Melalui matakuliah ini mahasiswa calon guru matematika dibekali dengan pengetahuan dan keterampilan yang dibutuhkan dalam mengajarkan vektor di sekolah.

Hasil observasi pada mahasiswa Pendidikan Matematika IKIP Budi Utomo menunjukkan bahwa masih banyak mahasiswa yang kesulitan dalam memahami konsep vektor. Konsep dalam Analisis Vektor sangat berhubungan dengan fisika (Sirait \& Oktavianty, 2017). Konsep fisika ini merupakan konsep yang abstrak (Musdar, 2015). Konsep yang abstrak ini akan lebih mudah dikuasai jika didukung dengan visualisasi yang baik. Visual berperan dalam mengkonkretkan ide, memotivasi peserta didik dengan menarik perhatian peserta didik, mempertahankan perhatian peserta didik dan dan berperan dalam menyederhanakan informasi yang sulit dipahami (Smaldino, et. al., 2005). Salah satu hal yang dapat dipertimbangkan untuk mengatasi permasalahan tersebut adalah penggunaan media pembelajaran.

Media pembelajaran merupakan salah satu komponen penting yang mampu mendukung keberhasilan pembelajaran. Media pembelajaran adalah segala sesuatu yang dapat menyampaikan pesan dari sumber secara terencana agar tercipta lingkungan belajar yang kondusif dimana penerimanya dapat melakukan proses belajar secara efektif dan efisien (Tim 
Fasilitator Pekerti-AA Kopertis Wilayah VII, 2014). Media pembelajaran ini menjadi perantara dalam mengkonkretkan konsep Analisis Vektor yang abstrak. Salah satu media yang dapat dijadikan alternatif dalam mendukung pembelajaran dengan memperhatikan prinsip visual adalah Prezi. Media pembelajaran ini merupakan media yang menerapkan teknologi canggih dan dirancang untuk mendukung pembelajaran Analisis Vektor.

Prezi merupakan aplikasi yang belum banyak digunakan dalam dunia pendidikan. Aplikasi ini hampir sama dengan PowerPoint dalam hal merancang presentasi. Aplikasi ini memberikan banyak pilihan dalam mengkreasikan dan menyimpan presentasi digital secara online (Perron \& Stearns, 2010). Prezi mampu memadukan kreativitas seseorang dengan teknologi modern dalam penggunaanya (Spernjak, 2014). Jadi berdasarkan berbagai pendapat di atas, dapat dikatakan bahwa Prezi merupakan aplikasi yang mampu memadukan kreativitas seseorang dengan kecanggihan teknologi untuk merancang presentasi digital berbasis online.

Aplikasi Prezi mempunyai beberapa keunggulan jika dibandingkan dengan PowerPoint yang sama-sama merupakan aplikasi yang dirancang untuk presentasi. Pembelajaran dengan menggunakan Prezi berpengaruh dalam kemampuan memahami konsep. Hal ini sesuai dengan pernyataan dari Akgun, et. al. (2016) yang menyatakan bahwa kemampuan mengingat dan memahami konsep pada peserta didik yang menggunakan Prezi lebih baik daripada yang menggunakan PowerPoint dalam pembelajarannya. Selain itu, juga diketahui bahwa peserta didik lebih menyukai Prezi dalam pembelajarannya daripada PowerPoint (Fox, et. al., 2016; Strasser, 2014). Penggunaan Prezi juga memberikan hasil yang lebih baik jika dibandingkan dengan PowerPoint dalam pembelajaran (Kiss, 2016). Berdasarkan kelebihan aplikasi Prezi tersebut penelitian bertujuan untuk mendeskripsikan pengembangan dan menghasilkan media pembelajaran berbasis Prezi yang layak digunakan dalam pembelajaran Analisis Vektor. Media ini ditujukan untuk mendukung pembelajaran Analisis Vektor dengan memperhatikan prinsip visual.

\section{METODE PENELITIAN}

Jenis penelitian merupakan penelitian pengembangan yang mengacu pada model ASSURE. Penelitian dilaksanakan di IKIP Budi Utomo Malang. Subyek penelitian merupakan mahasiswa program studi Pendidikan Matematika yang menempuh matakuliah Analisis Vektor. Lokasi dan subyek penelitian dipilih dengan pertimbangan bahwa kemampuan 
visualisasi mahasiswa masih rendah dalam memahami materi Analisis Vektor. Selain itu, belum adanya adopsi inovasi media pembelajaran dan mendukung pembelajaran tersebut.

Penelitian menerapkan pendekatan kualitatif dan kuantitatif. Pendekatan kualitatif mengacu pada data deskriptif saran perbaikan dari ahli materi dan media pembelajaran. Sedangkan pendekatan kuantitatif mengacu pada skor penilaian dari ahli dan respon mahasiswa serta hasil penilaian tes. Media pembelajaran yang dikembangkan dikatakan layak digunakan jika mengacu pada aspek kevalidan dan keefektifan sebagaimana terlihat pada tabel 1. Aspek kevalidan ditinjau dari hasil penilaian ahli materi dan media. Sedangkan aspek keefektifan ditinjau dari hasil penilaian angket respon mahasiswa dan tes evaluasi. Berdasarkan penilaian dari aspek kevalidan dan keefektifan tersebut maka instrumen penelitian yang dibutuhkan adalah lembar validasi ahli materi dan media, angket respon mahasiswa dan soal evaluasi. Metode pengumpulan data terdiri dari penilaian ahli, pemberian soal tes dan angket respon mahasiswa.

Tabel 1. Indikator aspek kevalidan dan keefektifan media

\begin{tabular}{ccl}
\hline Aspek & \multicolumn{1}{c}{ Instrumen } & \multicolumn{1}{c}{ Indikator } \\
\hline Kevalidan & 1. Lembar validasi & 1.1 Cakupan materi \\
& ahli materi & 1.2 Akurasi materi \\
& 1.3 Merangsang keingintahuan \\
& 2. Lembar validasi & 2.1 Penyajian \\
ahli media & 2.1 .1 Teknik penyajian \\
& 2.1 .2 Pendukung penyajian materi \\
& 2.1 .3 Penyajian pembelajaran \\
& & 2.2 Kebahasaan \\
& 2.2 .1 Sesuai dengan perkembangan peserta didik \\
& 2.2 .2 Komunikatif \\
& & 2.2 .3 Lugas \\
& & 2.2 .4 Koherensi dan keruntutan alur piker \\
& & 2.2 .5 Kesesuaian dengan kaidah Bahasa Indonesia yang benar \\
Keefektifan & Angket respon & Kelengkapan media \\
& & Kemudahan dalam menggunakan media \\
& & Kemampuan mahasiswa dalam memahami konsep \\
\hline
\end{tabular}

Lembar validasi ahli memuat penilaian dari ahli tentang kevalidan modul. Lembar validasi juga memuat saran dan komentar untuk perbaikan media yang dikembangkan. Validasi dilakukan pada ahli materi dan media. Angket respon mahasiswa memuat penilaian mahasiswa terhadap kemudahan dan kelengkapan media yang dikembangkan dalam pembelajaran Analisis Vektor. Soal tes digunakan untuk mengukur pemahaman mahasiswa terhadap materi Analisis Vektor. Media dikatakan valid jika rata-rata hasil validasi dari ahli materi dan media minimal mencapai kriteria valid sebagaimana terlihat pada tabel 2. Dari tabel 3, media dikatakan efektif jika rata-rata penilaian berdasarkan angket respon mahasiswa 
minimal pada kriteria baik dan rata-rata hasil tes mahasiswa berada pada kriteria cukup baik yaitu minimal mencapai nilai 55 .

Tabel 2. Kriteria Penilaian Validator Ahli

\begin{tabular}{cc}
\hline Skor Rata-Rata Penilaian & Kriteria Penilaian \\
\hline $3 \leq X \leq 4$ & Valid \\
$2 \leq X<3$ & Cukup valid \\
$1 \leq X<2$ & Kurang valid \\
$0 \leq X<1$ & Tidak valid \\
\hline
\end{tabular}

Tabel 3. Kriteria Penilaian Angket Respon Mahasiswa

\begin{tabular}{cc}
\hline Skor Rata-Rata Penilaian & Kriteria Penilaian \\
\hline $3 \leq X \leq 4$ & Sangat baik \\
$2 \leq X<3$ & Baik \\
$1 \leq X<2$ & Cukup baik \\
$0 \leq X<1$ & Kurang baik \\
\hline
\end{tabular}

Pengembangan media ini mengacu pada model ASSURE yang mengacu pada prinsip visual. Model pengembangan terdiri dari enam tahap, yaitu Analyze learners; State objectives; Select methods, media and materials; Utilize media and materials; Require learners' participation; dan Evaluate and revise (Smaldino, et. al., 2005). Tahap pertama yaitu analyze learners, merupakan tahap untuk menganalisis peserta didik. Analisis peserta didik terdiri dari analisis karakteristik peserta didik. Tahap kedua yaitu state objectives, merupakan tahap untuk menetapkan tujuan pembelajaran secara spesifik. Sebelum menetapkan tujuan pembelajaran sebaiknya pengembang mengeksplor terlebih dahulu bagaimana menggunakan prinsip visual dalam mendukung pembelajaran peserta didik. Tahap ketiga yaitu select methods, media and materials, merupakan tahap untuk menentukan metode, media dan materi pembelajaran. Tahap keempat yaitu utilize media and materials, merupakan tahap memanfaatkan media dan materi untuk mendukung pembelajaran. Tahap kelima yaitu require learner participation, mensyaratkan adanya partisipasi peserta didik. Tahap terakhir yaitu evaluate and revise, merupakan tahap yang penting untuk mengevaluasi apakah pembelajaran dengan melibatkan prinsip visual ini membantu peserta didik dalam pembelajaran. Perbaikan juga dilakukan berdasarkan hasil evaluasi yang dilakukan sebelumnya. 


\section{HASIL DAN PEMBAHASAN}

Penelitian ini bertujuan untuk mendeskripsikan pengembangan dan menghasilkan media pembelajaran berbasis Prezi yang valid dan efektif. Pengembangan media dijabarkan melalui enam tahap ASSURE.

\section{Analyze Learners}

Tahap ini merupakan tahap awal dalam pengembangan media. Pada tahap ini dilakukan analisis karakteristik peserta didik yang dalam hal ini adalah mahasiswa program studi Pendidikan Matematika IKIP Budi Utomo Malang. Tahap ini dilakukan dengan observasi dan wawancara terhadap dosen dan mahasiswa yang menempuh matakuliah Analisis Vektor. Berdasarkan hasil observasi dan wawancara diketahui bahwa mahasiswa masih kesulitan dalam mempelajari konsep analisis vektor yang abstrak. Mahasiswa kesulitan dalam menguasai istilah-istilah dasar vektor hingga penerapan vektor dengan diferensiasi dan integrasi. Padahal konsep Analisis Vektor ini merupakan salah satu bekal pengetahuan dan keterampilan yang harus dikuasai mahasiswa calon guru matematika. Oleh karena itu dibutuhkan bantuan untuk memudahkan mahasiswa dalam memahami konsep Analisis Vektor yang abstrak tersebut. Bantuan ditekankan pada adanya visualisasi dalam pembelajaran. Visualisasi ini diwujudkan dalam media pembelajaran yang dijadikan sebagai perantara dalam mengkonkretkan konsep Analisis Vektor yang abstrak.

\section{State Objective}

Pada tahap ini ditentukan tujuan pembelajaran secara spesifik. Tujuan atau capaian pembelajaran adalah mahasiswa mampu mengidentifikasi dan mengaplikasikan vektor untuk memecahkan permasalahan-permasalahan, khususnya dalam geometri. Tujuan tersebut disesuaikan dengan kurikulum yang digunakan. Selain itu, tujuan juga mengacu pada prinsip visual yang diterapkan yaitu salah satunya untuk memecahkan masalah geometri yang lebih banyak menggunakan visualisasi. Tujuan pengembangan ini adalah mendeskripsikan pengembangan dan menghasilkan media pembelajaran berbasis Prezi yang layak digunakan dalam pembelajaran Analisis Vektor.

\section{Select Methods, Media and Materials}

Pada tahap ini dipilih metode, media dan materi yang sesuai untuk mencapai tujuan pembelajaran yang dikemukakan dalam pembahasan sebelumnya. Secara umum, pembelajaran 
dirancang melalui kegiatan diskusi dan pemberian tugas. Untuk mencapai tujuan pembelajaran yaitu mahasiswa mampu mengidentifikasi dan mengaplikasikan vektor untuk memecahkan permasalahan-permasalahan, khususnya dalam geometri maka materi dalam Analisis Vektor dibagi menjadi beberapa bagian. Materi tersebut merupakan bekal bagi mahasiswa calon guru agar mempunyai pengetahuan dan keterampilan dalam mengajarkan vektor di sekolah. Materi tersebut terdiri dari lima pokok bahasan, yaitu vektor dan skalar; hasil kali titik dan silang; diferensiasi vektor; gradient, divergensi dan curl; dan integrasi vektor. Materi ini mengacu pada buku Analisis Vektor dari Spiegel $(1959 ;$ 1994). Indikator-indikator masing-masing pokok bahasan disajikan dalam tabel 4 berikut ini.

Tabel 4. Indikator pembelajaran analisis vektor

\begin{tabular}{|c|c|c|}
\hline No & Pokok Bahasan & Indikator \\
\hline \multirow[t]{4}{*}{1.} & Vektor dan skalar & 1.1 Menemukan definisi vektor dan skalar \\
\hline & & 1.2 Membedakan vektor dan skalar \\
\hline & & 1.3 Mengaplikasikan vektor dan skalar pada geometri dan fisika \\
\hline & & 1.4 Menyusun persamaan vektor garis lurus \\
\hline \multirow[t]{4}{*}{2.} & Hasil kali titik dan silang & 2.1 Menghitung hasil kali titik dan silang dari dua vector \\
\hline & & 2.2 Menghitung hasil kali triple vektor \\
\hline & & 2.3 Membedakan hasil titik dan silang \\
\hline & & 2.5 Mengaplikasikan hasil kali vektor pada geometri \\
\hline \multirow[t]{5}{*}{3.} & Diferensiasi vektor & 3.1 Mendeskripsikan derivatif fungsi vektor \\
\hline & & 3.2 Menyatakan titik dari kurva ruang dengan vektor posisi \\
\hline & & 3.3 Menentukan vektor tangent \\
\hline & & $\begin{array}{l}\text { 3.4 Menyebutkan syarat-syarat kontinuitas dan diferensiabilitas fungsi } \\
\text { vector }\end{array}$ \\
\hline & & 3.5 Menentukan derivatif parsial \\
\hline \multirow[t]{4}{*}{4.} & Gradien, divergensi dan curl & 4.1 Menggunakan operator diferensial \\
\hline & & 4.2 Menentukan gradien fungsi scalar dan derivatif arah \\
\hline & & 4.3 Menentukan divergen fungsi vektor \\
\hline & & 4.4 Menentukan curl medan vektor \\
\hline \multirow[t]{4}{*}{5.} & Integrasi vektor & 5.1 Menghitung integral biasa \\
\hline & & 5.2 Menghitung integral garis \\
\hline & & 5.3 Menghitung integral luas \\
\hline & & 5.4 Menghitung integral volume \\
\hline
\end{tabular}

Media pembelajaran berbasis Prezi dipilih karena belum adanya media pembelajaran inovatif yang mendukung pembelajaran matakuliah Analisis Vektor khususnya bagi mahasiswa program studi Pendidikan Matematika IKIP Budi Utomo. Selain itu, Prezi dipilih karena mudah digunakan, memperhatikan prinsip visual dan memudahkan dalam memahami konsep yang abstrak. Media berbasis Prezi ini terdiri dari lima bagian, yaitu vektor dan skalar; hasil kali titik dan silang; diferensiasi vektor; gradient, divergensi dan curl; dan integrasi vektor. Selain lima bagian utama, juga terdapat bagian judul dan menu awal dari media seperti gambar 1 . 


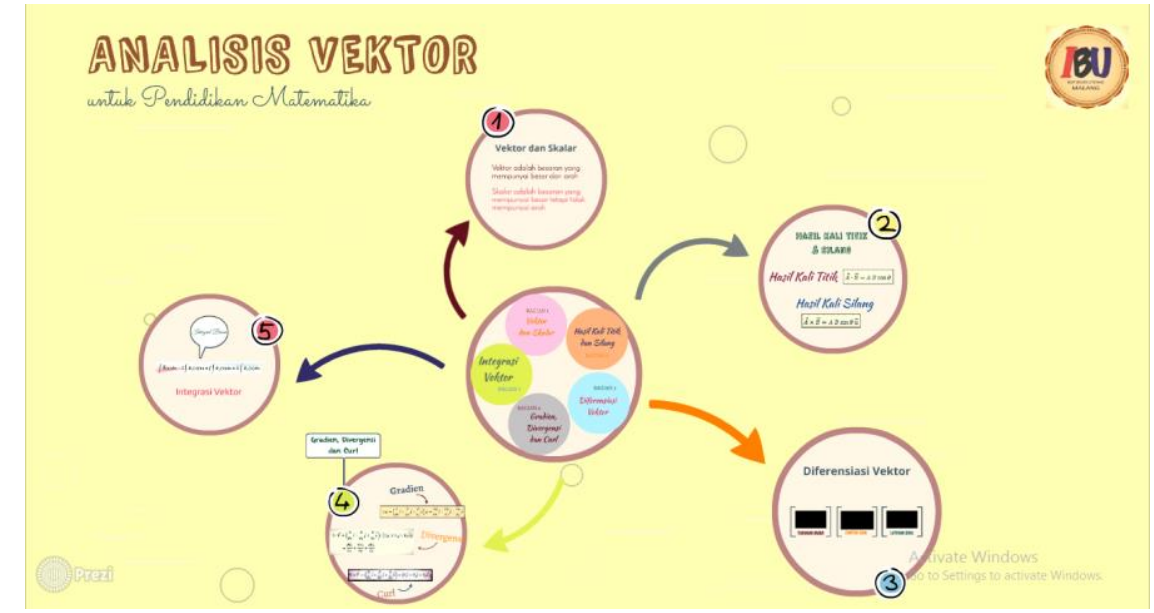

Gambar 1. Bagian Prezi yang Memuat Judul dan Menu Utama

Gambar 2 dan 3 memperlihatkan bagian per-bagian dalam media pembelajaran Prezi dapat diperbesar dan diperkecil sesuai kebutuhan.

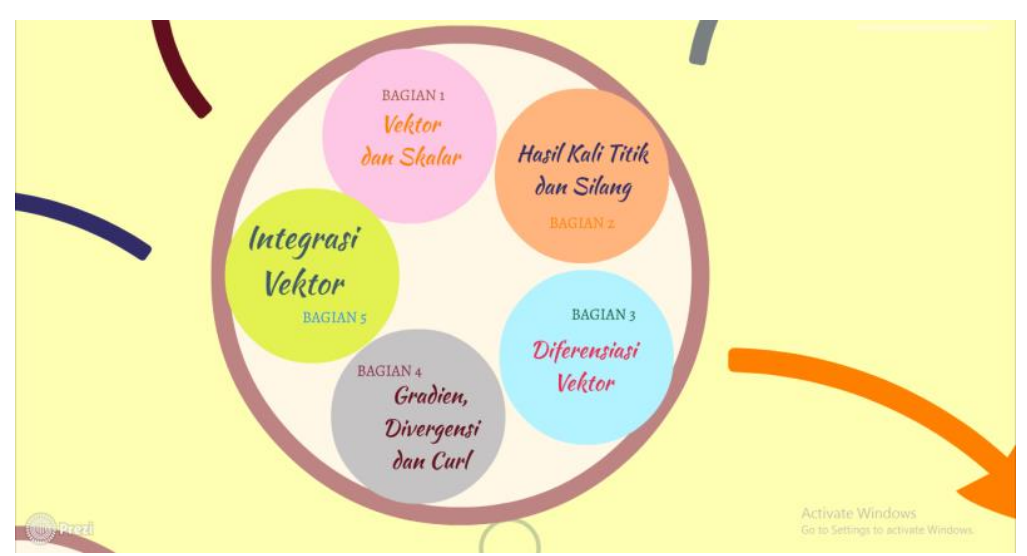

Gambar 2. Bagian yang Memuat Kelima Bab

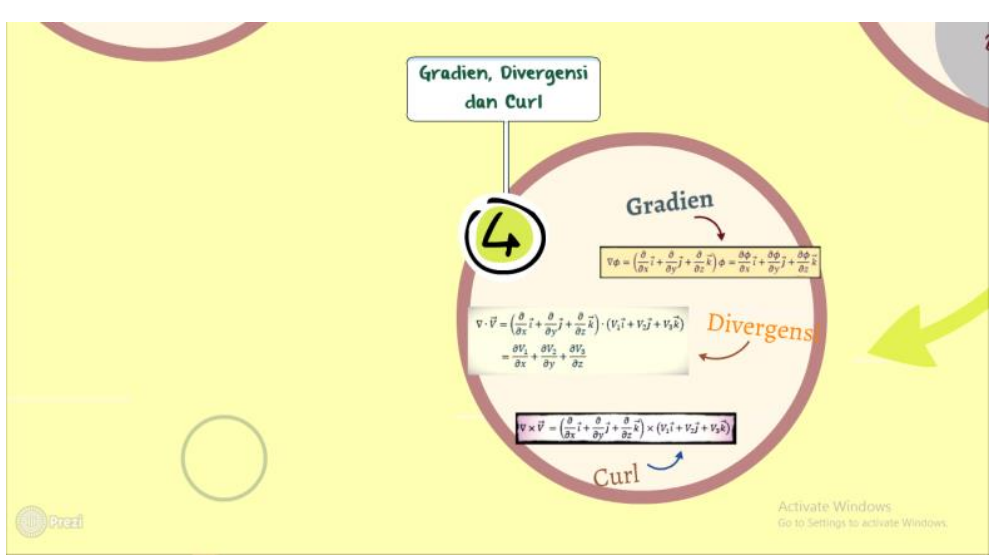

Gambar 3. Contoh Bagian yang Memuat Bab 4

Dalam masing-masing bagian juga dapat disisipkan file lain seperti PDF, Powerpoint, dan video. Pada gambar 4 di bawah ini terdapat bagian dari media yang memuat video 
pembelajaran. Video tersebut merupakan visualisasi dari konsep dasar dalam turunan biasa vektor seperti disajikan dalam gambar 5.

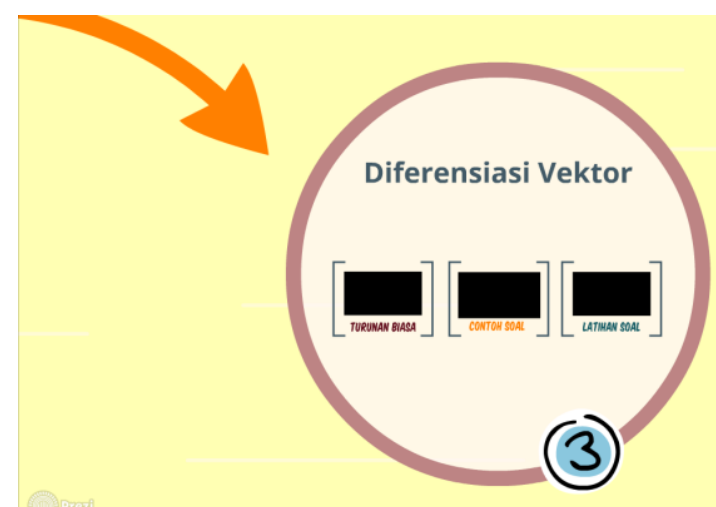

Gambar 4. Contoh Bagian yang Memuat Video

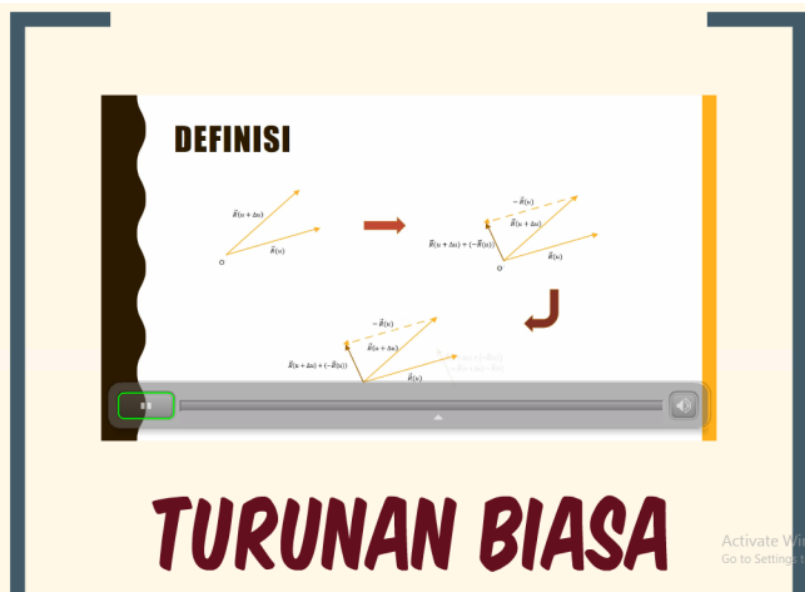

Gambar 5. Tampilan Video dalam Media

Sebelum diterapkan dalam pembelajaran maka dilakukan penilaian terhadap media yang sudah dikembangkan. Penilaian dilakukan oleh ahli materi dan media yang merupakan dosen pengampu matakuliah Analisis Vektor. Berdasarkan hasil penilaian ahli materi dan media diperoleh rata-rata 3,79 yang berada pada kriteria valid sebagaimana terlihat pada tabel 5. Kriteria ini menunjukkan bahwa media memenuhi aspek kevalidan untuk dikatakan layak digunakan dalam pembelajaran Analisis Vektor.

Tabel 5. Hasil penilaian ahli

\begin{tabular}{lcc}
\hline \multicolumn{1}{c}{ Validator } & Penilaian & Keterangan \\
\hline Ahli 1 & 3,86 & Valid \\
Ahli 2 & 3,71 & Valid \\
Rata-rata & 3,79 & Valid \\
\hline
\end{tabular}




\section{Utilize Media and Materials dan Require Learner Participation}

Kedua tahap ini dapat dilakukan secara bersamaan ketika menerapkan media yang dikembangkan dalam pembelajaran. Pada tahap awal mahasiswa dikenalkan dengan media yang digunakan untuk mendukung pembelajaran. Selanjutnya mahasiswa dilibatkan dalam pembelajaran yang secara umum terdiri dari kegiatan diskusi dan pemberian tugas. Tahap ini sekaligus merupakan kegiatan ujicoba terhadap media yang dikembangkan. Mahasiswa terlibat aktif dalam pembelajaran mulai kegiatan diskusi dan pemberian tugas melalui pemecahan masalah vektor dengan didukung media pembelajaran. Setelah penggunaan media dilakukan pemberian tes dan pengisian angket respon mahasiswa terhadap media pembalajaran.

\section{Evaluate and Revise}

Pada tahap terakhir ini dilakukan evaluasi dan perbaikan terhadap pembelajaran khususnya melalui media yang dikembangkan. Evaluasi dilakukan berdasarkan hasil tes pemahaman dan angket respon mahasiswa. Rata-rata hasil tes pemahaman mahasiswa berada pada kriteria cukup baik $(67,6)$ dan rata-rata angket respon mahasiswa berada pada kriteria sangat baik $(3,83)$. Berdasarkan hasil tes dan angket respon tersebut dapat dikatakan bahwa media yang dikembangkan efektif dalam pembelajaran Analisis Vektor. Perbaikan juga dilakukan untuk semakin meningkatkan pemahaman mahasiswa dalam pembelajaran tersebut.

Perbaikan media yang dikembangkan mengacu pada penilaian ahli. Saran perbaikan yang pertama adalah menambah latihan soal. Saran perbaikan yang kedua adalah pada pembagian materi lebih difokuskan pada bab apa yang akan dibahas misal pada definisi vektor dan skalar maka yang diperbesar adalah bagian 1 yaitu Vektor dan Skalar sedangkan bagian yang lain tidak perlu terlihat. Saran perbaikan yang ketiga adalah gambar judul pada bagian 4 sebaiknya tidak merujuk pada salah satu materi saja sehingga akan membuat rancu pengguna media.

\section{Pembahasan}

Media pembelajaran berbasis Prezi dikembangkan melalui enam tahap ASSURE. Berdasarkan keenam tahap tersebut, diperoleh bahwa media yang dikembangkan memenuhi aspek kevalidan dan keefektifan. Oleh karena itu, media pembelajaran berbasis Prezi yang dikembangkan layak digunakan dalam pembelajaran Analisis Vektor. Namun, media berbasis 
Prezi hanya terbatas penggunaannya di lingkungan mahasiswa program studi Pendidikan Matematika IKIP Budi Utomo Malang.

Media pembelajaran dikembangkan untuk memudahkan mahasiswa dalam memahami konsep Analisis Vektor yang abstrak. Media pembelajaran berbasis Prezi ini mempertimbangkan prinsip visual dalam pembelajaran. Visual berperan dalam mengkonkretkan ide, memotivasi peserta didik dengan menarik perhatian peserta didik, mempertahankan perhatian peserta didik dan dan berperan dalam menyederhanakan informasi yang sulit dipahami (Smaldino, et. al., 2005). Jadi hal ini sesuai untuk diterapkan dalam pembelajaran Analisis Vektor yang konsepnya abstrak.

Media pembelajaran Prezi belum banyak digunakan dalam dunia pendidikan, khususnya di lingkungan IKIP Budi Utomo. Prezi mempermudah pengguna dalam memahami dan menggunakan format yang menarik perhatian (Elnakib, 2018). Prezi merupakan pilihan yang tepat untuk memberikan penekanan terhadap hubungan dalam konsep (Strasser, 2014). Di samping itu, Prezi juga mampu memberikan kesempatan untuk mengkombinasikan kemampuan berpikir kreatif dengan teknologi modern untuk menciptakan presentasi yang interaktif dan terstruktur seperti peta konsep (Spernjak, 2014). Jadi, baik yang mengembangkan maupun yang menggunakan media pembelajaran berbasis Prezi mendapatkan kesempatan untuk belajar dan mengembangkan potensi diri dalam dunia pendidikan.

\section{KESIMPULAN}

Media pembelajaran Prezi mampu mendukung pembelajaran Analisis Vektor dengan memperhatikan prinsip visual. Media pembelajaran dikembangkan dengan mengacu pada model pembelajaran ASSURE yang terdiri dari enam tahap, yaitu Analyze learners; State objectives; Select methods, media and materials; Utilize media and materials; Require learners' participation; dan Evaluate and revise. Media yang dikembangkan layak digunakan dalam pembelajaran Analisis Vektor bagi mahasiswa Pendidikan Matematika IKIP Budi Utomo Malang. Media yang layak ini memenuhi aspek kevalidan dan keefektifan. Penilaian aspek kevalidan berdasarkan lembar penilaian ahli berada pada kriteria valid. Penilaian aspek keefektifan berdasarkan hasil tes mahasiswa berada pada kriteria cukup baik dan angket respon mahasiswa berada pada kriteria sangat baik. 


\section{REKOMENDASI}

Untuk penelitian selanjutnya dapat dikembangkan media pembelajaran yang lebih inovatif untuk mendukung pembelajaran Analisis Vektor maupun pembelajaran matakuliah lainnya.

\section{TERIMAKASIH}

Terima kasih kami ucapkan pada Lembaga Penelitian dan Pengabdian kepada Masyarakat (P2M) IKIP Budi Utomo Malang dalam mendukung penelitian penulis melalui Penelitian Dana Internal Tahun 2017 dengan SK No. 173/IKIP-BU/P2M/VII/2017.

\section{REFERENSI}

Akgun, Ozcan E., Babur, Aslihan \& Albayrak, Ebru. (2016). Effects of Lectures with PowerPoint or Prezi Presentations on Cognitive Load, Recall, and Conceptual Learning. International Online Journal of Educational Sciences, 8(3), 1-11.

Elnakib, S. (2018). Use of Prezi Sofware to Support and Expand Extension Outreach and Education. Journal of Extension, 56(1), n1.

Fox, H., Worasuwankumutinee, Werwe, J.W., \& Metcher, R. (2016). Prezi Versus Powerpoint in the Classroom. Makalah disajikan dalam Proceeding of $63^{\text {th }}$ The International Conference, Phuket, Thailand, 28 Februari.

Kiss, G. (2016). MS Power Point vs Prezi in Higher Education. Turkish Online Journal of Educational Technology-TOJET, 15(3), 126-130.

Musdar. (2015). Hubungan Kemampuan Matematika terhadap Prestasi Belajar Siswa dalam Pemecahan Masalah pada Kinematika Analisis Vektor di SMA Negeri 4 Banda Aceh. Jurnal Fisika Edukasi, 2(2), 102-107.

Perron, B. E., \& Stearns, A. G. (2011). A Review of a Presentation Technology: Prezi. Research on Social Work Practice, 21(3), 376-377.

Sari, M., Werdhiana, I. K. \& Wahyono, U. (2015). Analisis Kemampuan Pemecahan Masalah Vektor yang Direpresentasikan dalam Konteks yang Berbeda pada Mahasiswa Calon Guru Fisika. Jurnal Pendidikan Fisika Tadulako, 3(4), 17-25. 
Sirait, J. H. \& Oktavianty, E. (2017). Analysis of Pre-Service Physics Teachers' Understanding of Vectors and Forces. Journal of Turkish Science Education, 14(2), 82-95.

Smaldino, S. E., Russell, J. D., Heinich, R. \& Molenda, M. (2005). Instructional Technology and Media for Learning $8^{\text {th }}$ edition. New Jersey: Pearson Education, Inc.

Spernjak, A. (2014). Is Prezi More Usefullness Education Tool Than PowerPoint?. ICEMST 2014, 406.

Spiegel, M. R. (1959). Schaum's Outline of Theory and Problems of Vector Analysis and an Introduction to Tensor Analysis. USA: McGraw-Hill, Inc.

Spiegel, M. R. (1994). Analiss Vektor dan Suatu Pengantar Analisis Tensor (Versi S1/ Metrik). Jakarta: Erlangga.

Strasser, N. (2014). Using Prezi in Higher Education. Journal of College Teaching \& Learning (Online), $11(2), 95$.

Tim Fasilitator Pekerti-AA Kopertis Wilayah VII. (2014). Modul Pelatihan Pengembangan Keterampilan Dasar Teknik Instruksional (Pekerti). Surabaya: Kopertis Wilayah VII. 
Argarini \& Sulistyorini 222 